\author{
Nina Salomonowna Parfenowa, Juriu PawŁowicz Golikow \\ Instytut Medycyny Doświadczalnej \\ Wydział Biochemii \\ ul. Akademika Pawłowa 12 \\ Sankt-Petersburg, Rosja \\ e-mail: nina.parf@mail.ru
}

\title{
MARCELI NENCKI W SANKT-PETERSBURGU (1891-1901)
}

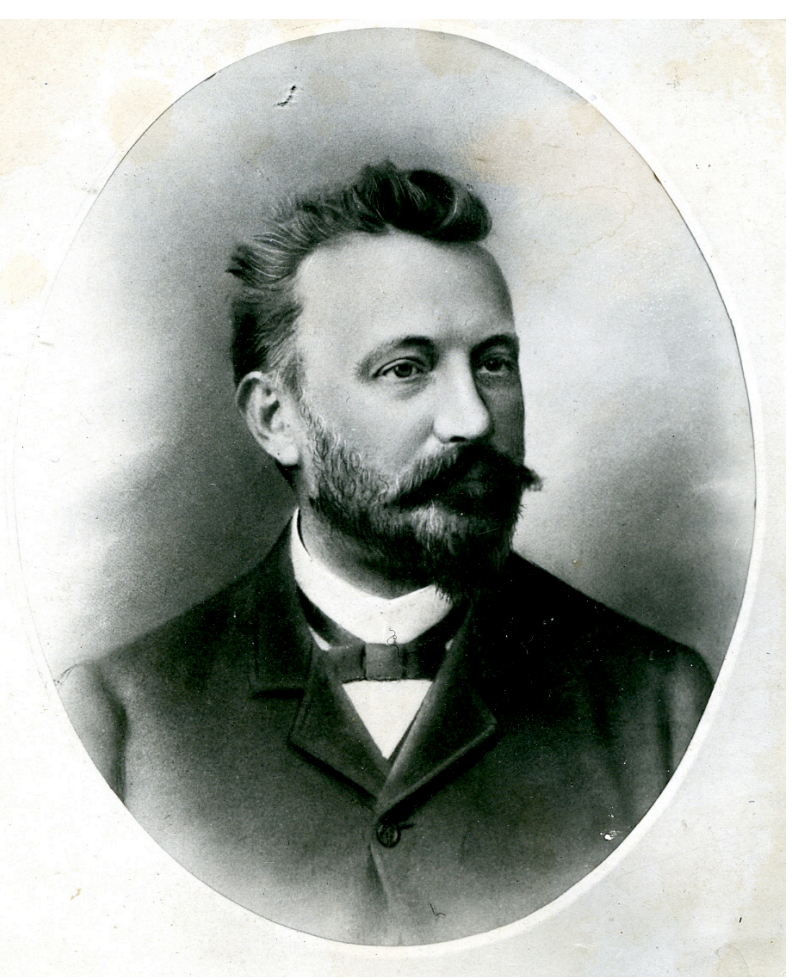

Profesor Marceli Nencki.

Marceli Nencki (1847-1901), światowej sławy chemik, lekarz fizjolog, mikrobiolog, współtwórca nowoczesnej chemii fizjologicznej (biochemii), a także wielki patriota. W 1870 r. ukończył studia medyczne na Uniwersytecie w Berlinie, po czym wstapił do Akademii Technicznej, gdzie w pra- cowni Adolfa von Baeyera zdobył gruntowne przygotowanie $z$ zakresu chemii oraz chemii organicznej. Dwa lata później objał stanowisko na Uniwersytecie $\mathrm{w}$ Bernie, gdzie też wkrótce został docentem, a od 1873 r. profesorem. W stworzonej dla niego Katedrze Chemii Fizjologicznej prowadził interesujące wykłady, które przyciagały uczonych $z$ wielu krajów. W latach 1888-1891 był także profesorem bakteriologii. W 1891 r. na prośbę władz carskiej Rosji zorganizował i objał na wiele lat kierownictwo Laboratorium Chemii Fizjologicznej $\mathrm{w}$ Imperatorskim Instytucie Medycyny Doświadczalnej w Sankt-Petersburgu. Prowadził badania nad synteza mocznika w organizmie zwierząt, określił rolę watroby $\mathrm{w}$ tym procesie $\mathrm{i}$ przedstawił (wraz $z$ Iwanem Pawłowem) jedna $z$ teorii powstawania mocznika u ssaków. Badając (w latach 1897-1901) barwnik krwi, jak też $i$ inne zwiazki barwne wykazał (wraz $z$ Leonem Marchlewskim) podobieństwo struktury chemicznej hemu i chlorofilu. Prowadzac w latach 1892-1895 badania nad cholera i księgosuszem u bydła zlecone mu przez Instytut, opracowal metody zwalczania tych zakaźnych chorób. Wynalazł także wykorzystywany do dzisiaj środek leczniczy zwany salolem.

Marceli Nencki (1847-1901), the world -famous chemist, physiologist, microbiologist, co-founder of modern physiological chemistry (biochemistry) and a great patriot. In 1870, he graduated from the University of Berlin in medical studies and then joined

Artykuł przygotowano na 100-lecie Instytutu Biologii Doświadczalnej PAN w Warszawie. Jest to przetłumaczony rozdział pt. „Маркец Вильгельмович Ненцкий в ИИЭМ (Marceli Wilhelmowicz Nencki w IIEM)” z książki zatytułowanej „Биохимия в институте экспериментальной медицины. 1890-2015. (Biochemia w Instytucie Medycyny Doświadczalnej. 18902015.)" wydanej w Instytucie Medycyny Doświadczalnej w Sankt-Petersburgu (Rosja). Rosyjski tekst rozdziału, za zgoda autorów, przetłumaczył profesor Stanisław Fabczak (Instytut Biologii Doświadczalnej im. M. Nenckiego; e-mail: s.fabczak@nencki.gov.pl). 
the Technical Academy, where he gained a thorough education at the Adolf von Baeyer laboratory in the field of chemistry and organic chemistry. Two years later, he took the position of assistant at the University of Bern, where he soon became a docent and then from 1973 - a professor. In the Department of Physiological Chemistry that was set up for him, he conducted interesting lectures that attracted scientists from many countries. In the years 1888-1891 he was also a professor in bacteriology. In 1891, at the request of the Russian tsarist authorities, he organized and took over for many years the leadership of the Laboratory of Physiological Chemistry at the Impe- rial Institute of Experimental Medicine in Saint-Petersburg. He conducted research on the synthesis of urea in animal organisms, described the role of liver in this process and presented (together with Ivan Pavlov) one of the theory of urea formation in mammals. Based on investigations on the blood pigment as well as other pigments (1897-1901), he showed (together with Leon Marchlewski) the similarity of the chemical structure heme and chlorophyll. Conducting (1892-1895) research on cholera and rinderpest in cattle, he developed methods to combat these infectious diseases. He also discovered a therapeutic drug salol, which is still in use.
Marceli Nencki, syn Wilhelma, urodził się 15 stycznia 1847 roku (daty do 1918 r. podawane sa według starego kalendarza) w Boczkach, w majątku rodzinnym ojca w powiecie kaliskim (Królestwo Polskie). Jego ojciec, wraz z matka Katarzyna Serwaczyńska, oprócz Marcelego posiadali jeszcze sześcioro dzieci. Ukończenie przez Marcelego Nenckiego gimnazjum w Piotrkowie i wstapienie na Wydział Filozoficzny na Uniwersytecie Jagiellońskim w Krakowie (1863) zbiegło się z rozpoczęciem w Królestwie Polskim Powstania Styczniowego. W tej sytuacji Nencki postanowił nie pozostawać na uboczu i wraz $z$ bratem Adamem dołaczył do powstańców. W zwiąku $z$ surowymi represjami nałożonymi przez cara po stłumieniu powstania był on zmuszony emigrować do Krakowa, znajdującego się w tym okresie pod zaborem austriackim, a następnie przeniósł się do Niemiec. Od kwietnia $1864 \mathrm{r}$. rozpoczał studia filozoficzne, początkowo na Uniwersytecie w Jenie, a od jesieni 1865 r. - na Uniwersytecie w Berlinie. Ostatecznie latem 1867 r. przeniósł się na Wydział Lekarski Uniwersytetu Berlińskiego. Równocześnie Nencki rozpoczał studia w zakresie chemii organicznej pod kierownictwem profesora Adolfa von Baeyera w Berlińskiej Akademii Technicznej i wyniósł stamtąd gruntowne przygotowanie chemiczne, a także rozległa wiedzę w tej dziedzinie. Nencki musiał szybko zwrócić na siebie uwage nowego mentora, skoro już w grudniu 1870 r. wprowadził go on do Niemieckiego Towarzystwa Chemicznego. W tych studenckich latach u Marcelego Nenckiego ukształtowały się główne zainteresowania naukowe dotyczace jego przyszłej działalności, ukierunkowane na badania procesów chemicznych zachodzacych w żywym organizmie.

Pierwsza prace naukowa Nencki wykonał wraz ze swoim berlińskim przyjacielem Ottonem Schultzenem i następnie opubliko- wał w 1869 r. w czasopiśmie „Berichte der Deutschen Chemischen Gesellschaft (Raporty Niemieckiego Towarzystwa Chemicznego)" na rok przed zakończeniem studiów uniwersyteckich. Dotyczyła ona badań źródła powstawaniu mocznika w organizmach zwierzęcych. W publikacji tej Nencki sformułował pytanie o fundamentalnym znaczeniu, a mianowicie $z$ czego $\mathrm{i}$ w konsekwencji $\mathrm{w}$ jaki sposób powstaje w organizmie zwierzęcia mocznik, znany już w tym czasie jako główny produkt metabolizmu białek. Na podstawie bezbłędnych, co do pomysłu i sposobu przeprowadzania doświadczeń, ówczesny student śmiało wystapił $z$ nowym jak na tamte czasy poglacdem przeczacym powszechnym opiniom o pochodzeniu mocznika. Nencki odrzucił ogólnie przyjęta wówczas opinię, że mocznik powstaje przez prosty rozpad białka. Zamiast tego, wysuną i jasno sformułował pogląd, że „powstawanie mocznika bez watpienia jest procesem syntezy". Oświadczenie takie zostało przedstawione w czasie, gdy naukowcy w ogóle skłonni byli przypisywać organizmowi zwierzęcemu niezwykle ograniczone zdolności do syntezy uważając, że takie właściwości sa charakterystyczne tylko dla roślin. Ponad 20 lat później Marceli Nencki powrócił do tego problemu, aby we wspólnych $z$ profesorem Iwanem Pawłowem i innymi współpracownikami badaniach, wzbogaconych o nowe podejścia fizjologiczne, w pełni potwierdzić prawdziwość własnych bardzo wczesnych wniosków, a także, aby je rozszerzyć i udoskonalić.

W 1870 r. Marceli Nencki, w wieku zaledwie 23 lat, obronił rozprawę doktorska pod tytułem Utlenianie zwiazków aromatycznych $w$ organizmie zwierzecia. W pracy tej uwidoczniła się znakomita zdolność Nenckiego do obserwacji, odwaga $\mathrm{w}$ wybieraniu tematów o istotnym, fundamentalnym znaczeniu, możliwość dokonywania szerokich uogólnień na podstawie właściwie dobranych wyników 
i dobrze przemyślanych doświadczeń. Później Nencki wielokrotnie i systematycznie powracał do tego tematu. W rezultacie wspólnie ze swoją współpracowniczka Nadieżdą Ziber-Szumowa opracował „test biochemiczny” pozwalajacy na pomiar poziomu utleniania benzenu do fenoli, co pozwoliło na ocenę intensywności procesów utleniania w ciele zwierzęcia. Nencki stosował go do badania wielu stanów patologicznych i stwierdził, że w leukemii, przy zatruciu fosforem, alkoholem lub po zażyciu narkotyków mocno obniża się zdolność utleniająca organizmu. Nie zaobserwowali tego zjawiska u osób chorych na cukrzycę, co skłoniło ich do sugestii, że procesy oksydacyjne $u$ tych osób nie ulegajac zahamowaniu, a istota cukrzycy leży w niemożności przekształcania cukru w kwas mlekowy. Nencki wraz $z$ Ziber-Szumowa opracowali również metodę wykrywania urobiliny w moczu na podstawie identyfikacji charakterystycznego pasma absorpcyjnego pojawiajacego się podczas analizy spektrofotometrycznej $\mathrm{w}$ widmie moczu po dodaniu kwasu siarkowego. Test ten nazwano „próba Nenckiego-Ziber".

Cała działalność naukowa i pedagogiczna Marcelego Nenckiego była bardzo wszechstronna i niezwykle bogata. Obejmowała ona szeroki zakres nauk w dziedzinie chemii, fizjologii medycznej i bakteriologii. Nie jest możliwym przedstawić ja w krótkim opisie i dlatego ograniczono się w tym artykule do syntetycznego przeglądu najważniejszych obszarów pracy Nenckiego w badaniach podstawowych, naukowo-praktycznych i działalności organizacyjnej w Szwajcarii i w Rosji.

Po ukończeniu Uniwersytetu w Berlinie Marceli Nencki otrzymał propozycję objęcia stanowiska asystenta w Katedrze Anatomii Patologicznej na Uniwersytecie w Bernie w Szwajcarii, którą przyjął, aby następnie szybko przejść dalsze szczeble kariery naukowej. W 1871 r. Nencki został „privat-docentem", a rok później profesorem nadzwyczajnym.

Podczas pobytu w Szwajcarii u młodego profesora nastapiły też zmiany w życiu osobistym. W czerwcu 1873 r. Marceli Nencki ożenił się $z$ Marią, siostrą swojego berlińskiego przyjaciela Otto Schultzena. Znał ją od czasów studenckich, kiedy była jeszcze żona grafa von Brockenburga. Po śmierci męża Maria przyjęła oświadczyny młodego naukowca i ślub odbył się w Berlinie. Wkrótce po ślubie oboje wrócili do Berna, gdzie w czerwcu 1874 r. urodził się im syn Leon. Maria nie przeniosła się razem z mężem w 1891 r. do Sankt-Petersburga, lecz pozostała w Berlinie, jej rodzinnym mieście. Relacje pomiędzy małżonkami pozostawały poprawne, o czym świadcza pisywane regularnie do siebie listy. Ostatni list Nenckiego $z$ Sankt-Petersburga jest datowany na dzień przed śmiercia naukowca. Nencki utrzymywał stały kontakt $z$ synem, śledzac jego postępy w nauce na Wydziale Lekarskim na Uniwersytecie w Bernie, a później prowadzone badania naukowe. Nencki przyczynił się nawet do publikacji dwóch artykułów syna w czasopiśmie „Архив биологических наук (Archiwum Nauk Biologicznych)".

Pierwszy swój artykuł $z$ dziedziny chemii organicznej Marceli Nencki opublikował w 1871 r., rozpoczynajac tym serię artykułów na temat badań grupy kwasu moczowego. W 1876 r. Nencki jako pierwszy ustalił obecność w czasteczce białka izomerów leucyny. $Z$ produktów rozkładu białek otrzymał on dwa izomery kwasów walerianowych, będacych wynikiem „przejścia oksydacyjnego" izomerów leucyny. Tak więc, po raz pierwszy została ustalona w czasteczce białka strukturalna izomeria aminokwasów. Pomimo zasług Nenckiego w ustaleniu tego faktu i opisaniu wyników badań w artykule pt. "К изучению лейиинов (Kи badaniom leucyny)" (1876), odkrycie izomerów leucyny do tej pory przypisuje się profesorowi Feliksowi Ehrlichowi, a nazwisko Nenckiego nie było nigdzie cytowane.

W 1877 r. Nencki zostaje profesorem zwyczajnym w utworzonej specjalnie dla niego Katedrze Chemii Fizjologicznej i kierownikiem Instytutu Medyczno-Chemicznego na Uniwersytecie w Bernie. Rok później przydzielono mu pomieszczenia w nowym budynku Instytutu Patologii, gdzie rozpoczał wykłady $z$ bakteriologii. W tym okresie osobiście znał i korespondował $z$ Emilem Teodorem Kocherem, szwajcarskim lekarzem i badaczem medycznym, który otrzymał Nagrodę Nobla w 1909 r. za swoja pracę w dziedzinie fizjologii, patologii i chirurgii tarczycy, Hermanem Sahli, lekarzem i profesorem na Uniwersytecie w Bernie i wynalazca hemiglobinometru, a także $z$ Hugonem Kronekerem i wieloma innymi znanymi naukowcami. W Bernie zaczęła się tworzyć szkoła naukowa Marcelego Nenckiego i do niego rozpoczęli przybywać uczniowie $z$ różnych krajów, w tym z Królestwa Polskiego czy też z Rosji.

Wiele swoich prac Nencki poświęcał tematom bliskim zagadnieniom praktyki lekarskiej i farmakologii. I tak, zsyntetyzował on w 1883 r. zwiazek, o nazwie salol (ester fenylowy kwasu salicylowego) jako środek do dezynfekcji jelita. „Zasada salolu Nenckiego" jest również obecnie stosowana w syntezie substancji leczniczych. Ta technika, w rzeczywistości, jest jedna $z$ pierwszych prób uzyskania proleków. Wśród wielu pojedynczych zwiazków o znaczeniu biochemicznym, 
badanych przez Nenckiego, na szczególna uwage zasługuja indol i skatol, otrzymywane $z$ produktów rozpadu białek. $Z$ kolei poprzez ozonowanie przekształcił on indol $\mathrm{w}$ indygo. Pierwszeństwo w tych badaniach profesor Adolf von Bayer przyznał Nenckiemu dopiero w $1900 \mathrm{r}$.

Wyjątkowe znaczenie miały też rozpoczęte w Szwajcarii w 1884 r. prace Nenckiego nad hemoglobina. Opracował on metodę otrzymywania heminy krystalicznej $z$ użyciem alkoholu amylowego (1884), która była pierwszym krokiem do dalszych badań w tym kierunku. Wspólnie ze swoimi współpracownikami, Nadieżdą Ziber-Szumową i Janem Zaleskim, otrzymał $z$ heminy hematoporfirynę i ustalił jej skład chemiczny. Badania te weszły na stałe do annałów światowej nauki. Profesor Edward E. Martinson (1953) słusznie uznał Nenckiego za twórcę nowoczesnej chemii porfiryn. W tym okresie rozpoczęła się też współpraca Nenckiego z Leonem Marchlewskim, który w Anglii, a później w Krakowie, pracował nad struktura barwnika liści, chlorofilu. Badania te były kontynuowane przez obu badaczy w późniejszym okresie, po przeprowadzce Nenckiego do Sankt-Petersburga w Rosji.

Pracownia Nenckiego w Bernie stawała się coraz bardziej znana $\mathrm{w}$ świecie naukowym, gdzie pod okiem mistrza rozpoczynali swoje badania młodzi naukowcy ze wszystkich krajów, nie tylko $z$ Europy, lecz również z Ameryki. Wśród nich były też siostry Szumowe, Nadieżda Ziber-Szumowa, asystentka Nenckiego oraz Katarzyna Szumowa-Simanowska, która po przeniesieniu się Nenckiego do Sankt-Petersburga została asystentka profesora Iwana Pawłowa. Poprzez siostry Szumowe, już od połowy lat osiemdziesiatych XIX wieku, Nencki utrzymywał stały kontakt $\mathrm{z}$ Pawłowem, który w tym czasie pracował $\mathrm{w}$ nowo powstałym Imperatorskim Instytucie Eksperymentalnej Medycyny $(\text { IIEM) })^{1)}$ w Sankt-Petersburgu.

Po otrzymaniu latem 1890 r. zaproszenia przez kuratora IIEM, księcia Aleksandra Oldenburgskiego do utworzenia Wydziału Chemii w IIEM, Nencki wydelegował na wstępne rozmowy do Sankt-Petersburga Nadieżdę Ziber-Szumowa. Przeprowadzone negocjacje zakończyly się sukcesem i w następnym roku Nencki wraz ze swoimi uczniami, Nadieżda Ziber-Szumowa, Szymonem Dzierzgowskim, Janem Zaleskim, Martinem Hahnem i Janem Zumpftem przybył do stolicy Rosji. Poczatkowo zamieszkał $\mathrm{w}$ domu dla pracowników na terenie Instytutu, a później wynajał mieszkanie w budynku nr 54 przy Bolszom prospekcie na Piotrogrodskiej stronie miasta.
Zatrudnienie Marcelego Nenckiego w Instytucie wymagało od kuratora, księcia Aleksandra Oldenburgskiego, wystosowania specjalnego pisma do Ministra Spraw Wewnętrznych Iwana Nikołajewicza Durnowa $z$ prośbą o powołanie Nenckiego na rzeczywistego członka Instytutu:

\section{Wasza Ekscelencja Iwan Nikołajewicz}

Pragnąc mianować Marcelego Nenckiego, Profesora Zwyczajnego na Uniwersytecie w Bernie, Rzeczywistym członkiem Imperatorskiego Instytutu Medycyny Doświadczalnej, mam zaszczyt pokornie prosić Wasza Wysokość na podstawie §44 Tymczasowego Statutu tego Instytutu i zapytać Najmiłosierniejszego Władcę Imperatora o zgodę na tę nominację.

Przyjmijcie Wasza Ekscelencjo wyrazy mojego najwyższego szacunku.

Książę Aleksander Oldenburgski

Tak więc, 5 czerwca 1891 r. Marceli Nencki został pełnoprawnym członkiem IIEM, jednego $z$ pierwszych na świecie centrum badawczego $\mathrm{w}$ dziedzinie biologii i medycyny, a 12 grudnia tegoż roku na walnym zgromadzeniu Rosyjskiego Towarzystwa Fizyko-Chemicznego został wybrany jego członkiem. Interesujace jest też pismo w sprawie zatwierdzenia prawa profesora Nenckiego do otrzymywania państwowego wynagrodzenia:

Rozporzadzenie $\mathrm{nr} 61$

Imperatorski Instytut Medycyny Doświadczalnej

Jego EKSCELENCJA IMPERATOR, 9 dnia czerwca tego roku, raczył pozwolić, aby Rzeczywistemu Członkowi Imperatorskiego Instytutu Medycyny Doświadczalnej, Kierownikowi Wydziału Chemicznego profesorowi M. Nenckiemu zaliczono do wystugi lat okres pracy na Uniwersytecie w Bernie, czyli od 7 lutego 1872 r. do 2 lipca $1891 \mathrm{r}$.

O tak nadzwyczajnym poleceniu zawiadomiono Imperatorski Instytut Medycyny Doświadczalnej.

Książę Aleksander Oldenburgski

Wydział Chemii rozpoczał systematyczną pracę 23 czerwca 1891 r., tymczasowo mieszczac się w głównym, drewnianym budynku IIEM. Nencki natychmiast rozpoczał przygotowanie technicznego planu dla przyszłego budynku laboratoryjnego. Uwzględniajac jego propozycje, znany architekt Ferdynand L. Miller stworzył projekt, według którego został wzniesiony budynek $\mathrm{w}$ rekordowym czasie i oddany do użytku już w grudniu 1892 r. Było to możliwe dzięki przekazaniu Instytutowi 200 tysięcy rubli przez petersburskich bankierów: Łazara Brodskiego, Horacego Ginzburga, Abrahama Zaka oraz I. Wawelberga na realizacje projektu, budowę i wyposażenie budynku. Do tej charytatywnej akcji zostali oni przekonani przez księcia Oldenburgskiego, kuratora IIEM. Od tamtego 


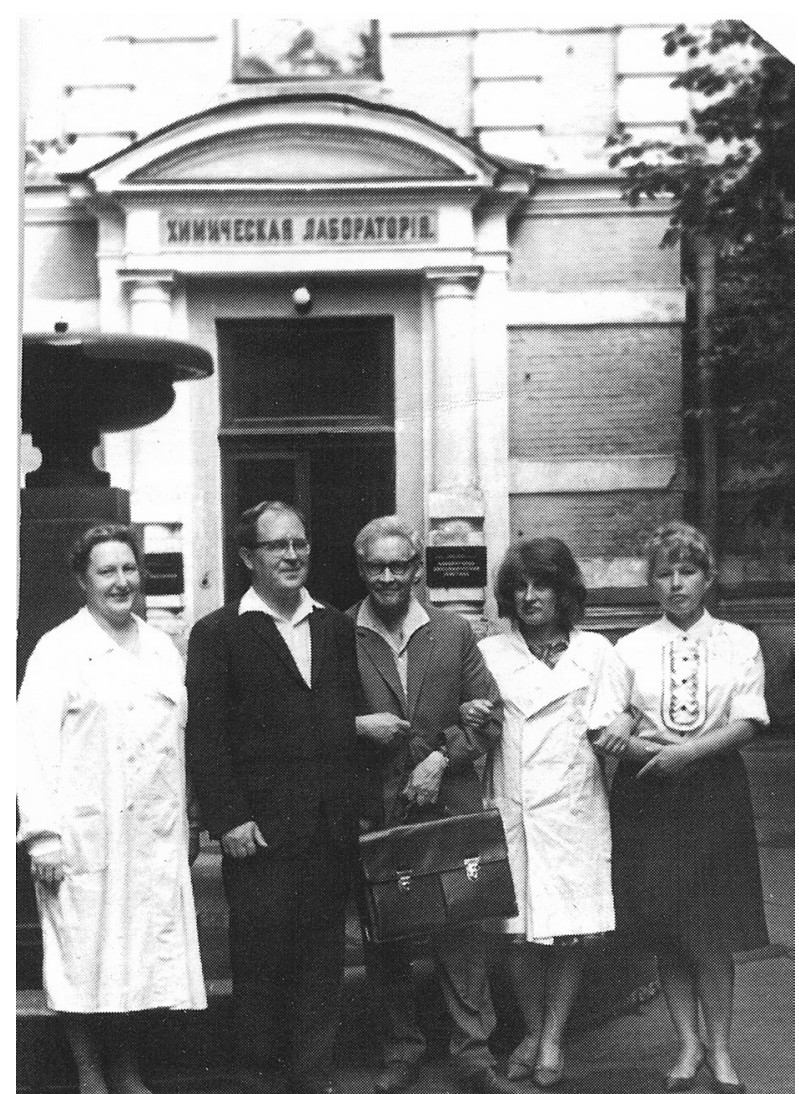

Ryc. 1. Front budynku „Laboratorium Chemiczne” (1970 r.)

czasu front budynku zdobi dobrze zachowany napis „Laboratorium Chemiczne” (Ryc. 1).

Właściwie wraz $z$ przybyciem Nenckiego do Sankt-Petersburga „rozpoczęła się nowa era w jego życiu i działalności, poświęcona głównie interesom naukowym", jak donosiła gazeta „Новое время (Nowy Czas)” z 5. (17.) marca 1897 r. w artykule poświęconym 25-leciu działalności naukowej i pedagogicznej profesora. Zaproszenie do pracy $\mathrm{w}$ IIEM było punktem zwrotnym w życiu uznanego naukowca, który wykazał się w tym czasie wybitnym naukowym dorobkiem. Aby Nencki mógł przenieść się do Sankt-Petersburga, to książę musiał otrzymać specjalne zezwolenie cara Aleksandra III na przyjazd byłego uczestnika Powstania Styczniowego w ówczesnym Królestwie Polskim. W Sankt-Petersburgu Nencki otrzymał nieporównanie lepsze warunki do rozwoju pracy badawczej, niż miał w Bernie. W IIEM otrzymał on dobrze wyposażone laboratorium, zbudowane i urzadzone ściśle według jego własnego projektu (Ryc. 2), był on całkowicie zwolniony od wykładów i innych zajęć dydaktycznych i cały swój czas mógł więc poświęcić pracy naukowo-badawczej. Ponadto, książę Oldenburgski zaproponował Nenckiemu niemałe wynagrodzenie w wysokości 3.000 rubli, a także 1.000 rubli „stołówkowych" oraz oso-
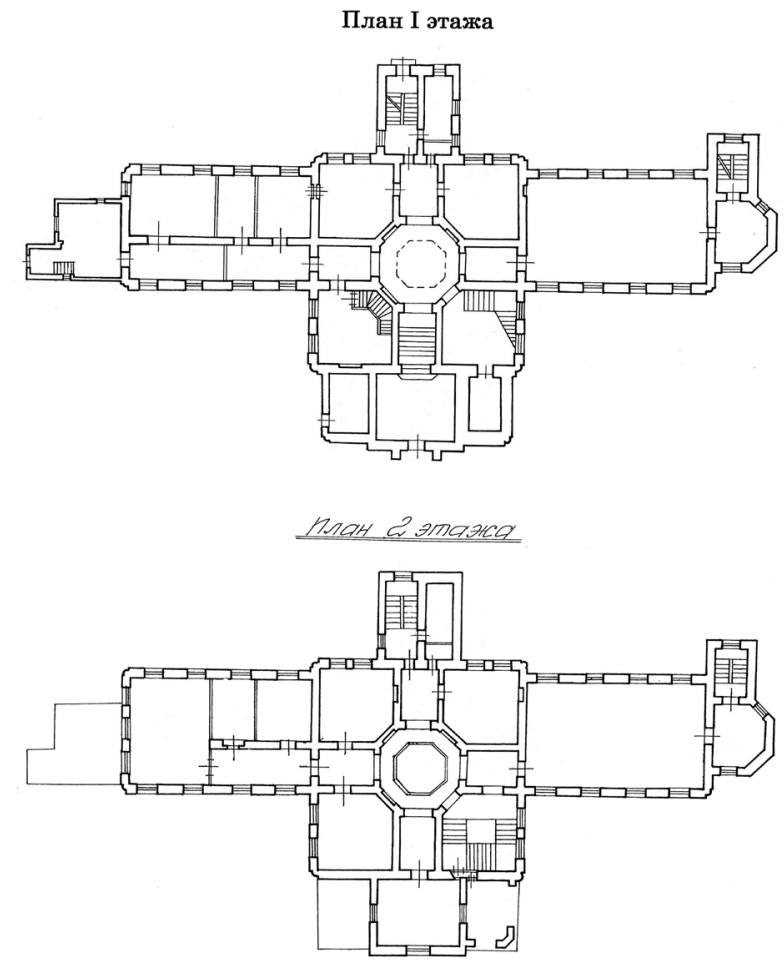

Ryc. 2. Projekt budynku Laboratorium Chemii

bisty dodatek w wysokości 2.000 rubli. Pozostali kierownicy wydziałów w Instytucie dodatku personalnego nie otrzymywali. $\mathrm{Na}$ podkreślenie zasługuje fakt, że powstanie IIEM stanowiło początek tworzenia się $w$ tym Instytucie głównych dyscyplin, biologii i medycyny. $Z$ założenia też zajmowano się w nim wyłącznie działalnościa naukowa, co pozwalało badaczom poświęcić swój czas tylko badaniom. Już przy organizacji IIEM, książę zaprosił do współpracy najlepszych teoretyków i eksperymentatorów tamtych lat. Byli to Siergej Winogradski (bakteriologia), K. J. Helman (weterynaria), Iwan Pawłow (fizjologia), Mikołaj W. Uskow (anatomia patologiczna), Edward Sperk (dermato-wenerologia), którzy kierowali wydziałami naukowymi.

Wśród tych, którzy pracowali w laboratorium Nenckiego (Ryc. 3) było wielu uciekinierów $z$ Królestwa Polskiego, wchodzacego wówczas w skład imperium rosyjskiego. Już od pierwszego roku działalności Nenckiego zaczęli przybywać obcokrajowcy skuszeni możliwością pracy pod kierunkiem słynnego naukowca, tacy jak: L. Rekowski, G. Manujłow (Austria), Jan Zumpft, Artur G. Blachstein (USA) i inni. W laboratorium tym odbywali staże również współpracownicy i praktykanci $z$ IIEM, którzy byli zainteresowani biochemia: Siergiej M. Winogradski, Aleksander A. Władimirow, Uszakow, Siergej S. Salazkin, Fiodor J. Czystowicz i inni. Po przybyciu do stolicy Rosji, Nencki i jego 


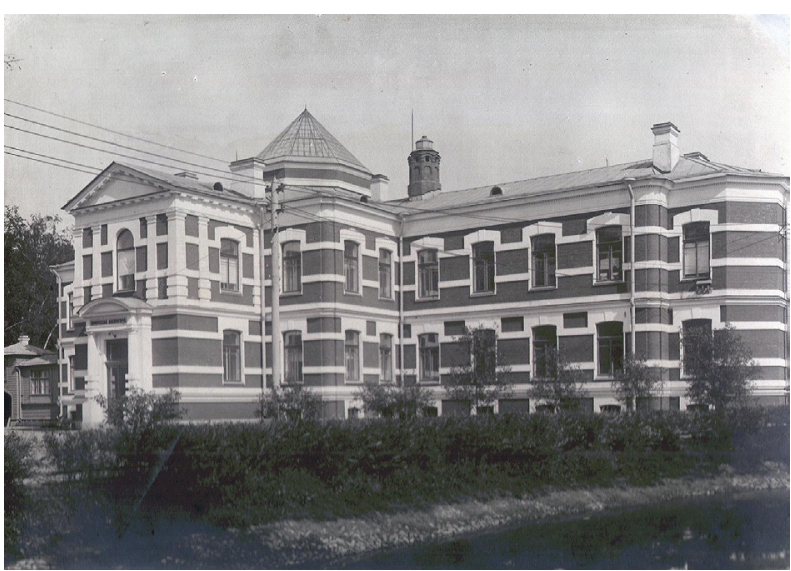

Ryc. 3. Budynek Laboratorium Chemii

współpracownicy natychmiast podjęli badania, kontynuując prace rozpoczęte $\mathrm{w}$ Bernie, tj. badania chemii porfiryn, biosyntezy mocznika, enzymów bakteryjnych powodujacych rozkład aminokwasów. Jak intensywnie pracował Nencki i jego współpracownicy świadczy znaczna liczba (16) publikacji, które sie ukazały $\mathrm{w}$ rok po ich przybyciu do Sankt-Petersburga.

Ścisła współpraca $z$ profesorem Iwanem Pawłowem. rozpoczęta po przybyciu Nenckiego do Sankt-Petersburga, pozwoliła mu na wykorzystanie nowego eksperymentalnego podejścia w celu rozwiązywania podstawowych problemów chemii medycznej. Już w 1892 r., wspólnie z Pawłowem, Hahnem i Massenem przeprowadził pierwsze w IIEM kompleksowe fizjologiczno-chemiczne badania, w których udowodniono, że wattroba jest głównym, lecz nie jedynym miejscem w organizmie zwierzęcia, gdzie powstaje mocznik, a bezpośrednim źródłem mocznika jest amoniak. Stało się to podstawa do potwierdzenia teorii, wysuniętej jeszcze w Bernie, o syntezie mocznika $\mathrm{w}$ organizmach ssaków. Powyższe wyniki, które budziły wątpliwości potwierdzili Nencki wraz $z$ Pawłowem i Zaleskim, badajac $z$ wykorzystaniem udoskonalonej metody oznaczania amoniaku we krwi, moczu i narzadach zwierzat. Metoda ta znalazła szerokie zastosowanie $\mathrm{w}$ pracach nad innymi zagadnieniami. Także powszechnie wykorzystywano metode oznaczania śladowych ilości mocznika za pomoca o-nitrobenzaldehydu, wynaleziona przez Nenckiego podczas jego prac nad produktami kondensacji mocznika $z$ aldehydami.

Marceli Nencki pracował również nad pochodna kwasu moczowego, indolem. W cyklu doświadczeń przeprowadzonych $\mathrm{w}$ jego laboratorium wykazano, że indol powstaje podczas trawienia trzustkowego. Według wyrażonego przez niego pogladu indol po- wstały w jelitach ulega resorpcji i utlenieniu we krwi na błękit indygo, a po połączeniu $z$ cukrem wydalany jest pod postacia indykanu. Odkrycie indolu skierowało uwage Nenckiego na zagadnienie rozpadu czasteczek białka pod wpływem różnych czynników chemicznych i zwiazany $z$ tym problem chemii białek. Duże znaczenie miała jego praca nad badaniem procesów fermentacji i rozkładu.

Szalejacca w 1892 r. epidemia cholery zmusiła Nenckiego chwilowo do zaprzestania prac fizjologiczno-chemicznych i do całkowitego poświęcenia czasu i środków do walki $z$ ta straszna plaga. W tym samym roku $z$ inicjatywy Nenckiego zorganizowano w IIEM dla zainteresowanych osób kursy, na których zapoznawano ich ze sposobami i środkami zwalczania infekcji. 23 czerwca 1892 r. Nencki wyruszył na wyprawe do Baku na Kaukazie „w celu zatrzymania epidemii cholery" i od razu przystapił tam, na miejscu do badań nad ta choroba. W późniejszym latach (1895 r. i 1898 r.) wyjeżdżał on kilkakrotnie w okresach epidemii księgosuszu (znanego też pod nazwa dżumy bydlęcej) wśród zwierząt gospodarskich. W trakcie tych wyjazdów Nencki przeprowadzał próby $z$ różnymi środkami dezynfekującymi i wykrył, że zwyczajny dziegieć brzozowy zabija bakterie cholery i wiele innych, bardziej skutecznie niż kwas karbolowy.

$\mathrm{Na}$ oczywiste pytanie, dlaczego Marceli Nencki będąc chemikiem zajał się w pewnym momencie bakteriologia, daje odpowiedź jego asystentka Ziber-Szumowa. „On przystapił do swoich prac nad bakteriologia w czasie, gdy ta nauka dopiero zaczynała powstawać i kiedy palace pytanie o „Generatio aequivoca" (o samorództwie organizmów) zajmowało umysły wszystkich i służyło jako temat żywej polemiki. Oczywistym było, że młody w tym czasie (wczesne lata 70. XIX wieku) Nencki nie mógł pozostać $z$ boku względem nowego nurtu, który mógł rzucić światło na interesujace go pytania".

Pod koniec XIX wieku na znacznej przestrzeni imperium rosyjskiego występowała również epidemia księgosuszu u owiec. Uznano ja za jedna $z$ najstraszniejszych narodowych klęsk. W przeglądzie literaturowym współpracownik Nenckiego Władysław Wyżnikiewicz podkreślał, że rozwiązywanie tej kwestii $z$ powodu niekorzystnych uwarunkowań zewnętrznych przebiegało zbyt wolno. Wprowadzone 3 lipca 1879 r. w wielu prowincjach imperium rozporządzenie, które nakazywało obowiazkowe zabijanie zainfekowanego bydła, jak i bydła, które kontaktowało się $z$ chorym zwierzęciem, przestało bowiem całkowicie być przestrzegane. „Wszystkie państwa Europy ponosiły ogromne stra- 
ty i wydały miliony na walkę $z$ nią" - pisał Nencki w liście do księcia Oldenburgskiego. W tej sytuacji w 1892 r. z inicjatywy księcia rozpoczęto badania nad księgosuszem, początkowo na Wydziale Epizootologii w IIEM, pod kierownictwem prof. E. Semmera oraz jego asystenta Michała Tartakowskiego, a później prowadzono je w terenie w majątku Magdenko w Połtawskiej gubernii. Profesor E. Semmer we wstepnym komunikacie na temat tych badań pisał, że osłabienie działania zarazków księgosuszu można osiagnaćc przez poddaniu ich działaniu niskiej lub wysokiej temperatury a także poprzez przepasażowanie ich przez organizm morskich świnek. Na podstawie tych wyników prof. Semmer doszedł do wniosku, że pomimo niedokończonych jeszcze doświadczeń, to „takie szczepienia sa odpowiednio przydatne do ochrony żywego inwentarza przed księgosuszem, który za pomoca zastosowania takiego środka może być usunięty $z$ Rosji znacznie taniej i w mniej drastyczny sposób, niż zabijanie zwierząt".

Poszukiwaniami radykalnych środków przeciwdziałajacych chorobom bydła w tamtym czasie byli bardzo zainteresowani właściciele dużych stad bydła, którzy w przypadku wystapienia epizoocji ponosili ogromne straty. W związku $z$ powyższym graf Aleksander W. Orłow-Denisow przekazał Instytutowi 60 tysięcy rubli na badania, $z$ czego 10 tysięcy rubli na nagrodec dla osoby, która wynajdzie skuteczny środek do walki $z$ zarazą. Także właściciele bydła na Północnym Kaukazie złożyli w 1894 r. wniosek do IIEM o „potrzebie weryfikacji naukowej” sposobów zwalczania zarazy i wyrazili potrzebę konieczności przeprowadzenia na szeroka skalę doświadczeń zwiazanych ze szczepieniem przeciwko księgosuszu u bydła. Właściciel gruntów, J. F. Nikolenko, zaproponował, aby do tego celu wykorzystać jego majątek położony w pobliżu stanicy Kardonikska w rejonie Batałpaszyńskim w obwodzie Kubańskim (północne zbocze góry Elbrus). "Ze względu na fakt, że w Instytucie znajdowały się kwoty przekazane wcześniej przez grafa Orłowa-Denisowa na badania nad księgosuszem i zgodnie też $z$ życzeniem księcia Oldenburgskiego oraz na wniosek Rady Instytutu postanowiono wyjść naprzeciw prośbie właścicieli ziemskich i zorganizować wyprawę pod kierownictwem profesora Marcelego Nenckiego".

Ministerstwa, Wojenne oraz Spraw Wewnętrznych (MWD), poparły to przedsięwzięcie i ostatecznie utworzono komisję, do której właczyły swoich przedstawicieli. Z Wojenno-Medycznej Akademii (W-MA) profesora W. E. Woroncowa oraz z MWD lekarza weterynarii N. I. Eckerta, „z udziałem także weterynarza S. W. Waganowa z Kubańskiej gubernii oraz przydzielonymi lekarzami weterynarii A. A. Dudukałowa i Władysława I. Wyżnikiewicza". Nencki, wyznaczony na kierownika wyprawy $z$ przyczyn od niego niezależnych nie mógł udać się na Północny Kaukaz, ale jego asystenci, Nadieżda Ziber-Szumowa i Jan Zaleski oraz oddelegowany do ekspedycji I. A. Kaczyński przeprowadzili latem 1895 r. badania etiologii księgosuszu celem znalezienia środka do walki $z$ nim. Sprawozdanie $z$ wyprawy zostało opublikowane w lipcu 1886 r. w czasopiśmie „Архива ветеринарных наук (Archiwum Nauk Weterynaryjnych)". Po zakończeni wyprawy badania były kontynuowane w IIEM w Sankt-Petersburgu. Nencki przedstawił wyniki dotychczasowych prac 8 maja 1897 r. na spotkaniu „Towarzystwa Rosyjskich Lekarzy" i bezpośrednio stwierdził, że „Wszystkie drobnoustroje, które opisane były przez różnych autorów jako czynniki wywołujące ksiegosusz nie maja nic wspólnego $z$ ta choroba (...)". Nenckiemu udało się wyizolować patogen księgosuszu i znaleźć środowisko, w którym się rozwija, ale nie udało się go sklasyfikować. Wykazał on, że surowica krwi zwierząt, które przeniosły zarazę posiada właściwości immunizujące.

W celu weryfikacji uzyskanych wyników w terenie i w IIEM oraz dla okazania pomocy lokalnym władzom w walce $z$ księgosuszem, Instytut razem $z$ MWD wysłał 28 grudnia 1897 r. praktykanta $z$ Wydziału Chemii Władysława I. Wyżnikiewicza do pracy w miasteczku Inkiewi w Tyfliskiej gubernii, zlokalizowanym w Ateńskim wąwozie, 18 wiorst od miasta Gori. Wyżnikiewicz jeszcze przed ta ekspedycja zdobył doświadczenie w walce $z$ zarazą. Po zakończeniu $z$ wyróżnieniem Instytutu Weterynarii w Charkowie w 1889 r. pracowal przez dwa lata w swojej klinice weterynaryjnej. Później w latach 1893-1896 MWD oddelegowało go do leczenia zarażonych księgosuszem zwierząt w rejonie Kubania, gdzie była rozmieszczona armia kozacka. To tam Wyżnikiewicz spotkał się $z$ Nenckim i jego współpracownikami i rozpoczął pracę pod jego kierunkiem. Wyżnikiewicz „za przyzwoleniem księcia Aleksandra Oldenburgskiego i za zgoda ministra MWD" urządził wraz z współpracownikiem Julianem Ławrynowiczem specjalna stację do produkcji szczepionek i leczenia zwierzat. Nencki i Ziber-Szumowa przyjechali na stację 6 miesięcy później. Od lutego 1898 r. Wyżnikiewicz $\quad z$ Ławrynowiczem przeprowadzili na stacji szczepienia ponad 800 byków, krów, cieląt, kóz i owiec.

Utworzona wcześniej komisja doszła do wniosku, że możliwe jest uzyskanie odporności na choroby u zwierząt, stosując suro- 
wicę przeciwko księgosuszowi. Jednak nadal nie było wystarczająco dużo materiału do pełnej oceny uzyskanych wyników. Nencki wraz z Ziber-Szumowa i Wyżnikiewiczem zastosowali „symultanicznie” szczepienia, to znaczy równoczesne podanie $z$ żywym wirusem konkretnej surowicy. Rada Naukowa Instytutu zleciła właśnie Nenckiemu uruchomienie produkcji oraz chemiczną kontrolę jakości szczepionek i surowicy w „Specjalnym Laboratorium IIEM przeznaczonym do przygotowywania preparatów przeciw księgosuszowi”. Poczatkowo, było ono zorganizowane w 1897 r. na terenie Instytutu, a w 1901 r. zostało przeniesione do fortu „Imperator Aleksander I" w pobliżu Kronsztadtu, gdzie pod kierownictwem architekta Grzegorza H. Lucedarskiego przygotowano pomieszczenia dla nowego laboratorium.

$Z$ inicjatywy Nenckiego opracowano i uruchomiono w IIEM produkcję różnych surowic. Prace te przez półtora roku prowadził Nencki, a następnie przekazał je swojemu współpracownikowi Szymonowi Dzierzgowskiemu. W 1894 r. uruchomiono produkcję $\mathrm{m}$. in. surowicy przeciw dyfterytowi i rozpoczęto seroterapię dyfterii. 13 grudnia 1894 r. Nencki wystapił w stołecznym Towarzystwie Lekarzy i w Towarzystwie Farmaceutycznym $z$ mocna obrona nowo wyprodukowanej surowicy dla leczenia błonicy. W następnym roku Nencki, badajac etiologie cholery i księgosuszu występujących wśród dużego rogatego bydła szczegółowo opracował proces produkcji surowicy odpornościowej w celu ochrony zwierząt przed zaraza. Opracowana przez niego i jego współpracowników metoda immunizacji zwierzat została zastosowana w dwóch stacjach weterynaryjnych IIEM (w Inkewi oraz w pobliżu Czity na Syberii). Obie stacje były zorganizowane przy wsparciu księcia Aleksandra Oldenburgskiego, Ministerstwa Wojny i ze środków finansowych przekazanych na ten cel przez grafa Aleksandra W. Orłowa-Denisowa.

Nencki kończąc w IIEM rozpoczęte w Szwajcarii prace osiagnał interesujace wyniki podczas badania hemoglobiny. Została opracowana metoda uzyskiwania czystego heminu i jego pochodnych. Poprzez dokładne analizy ustalono ich podstawowy skład, opisano najważniejsze funkcje i podano przypuszczalne wzory strukturalne. Badajac, oprócz krwi, i inne barwniki występujace w żółci, moczu oraz chlorofil, Nencki wykazał ich podobieństwo strukturalne i powinowactwo chemiczne, albo poprzez przekształcenie jednego w drugi, lub przez uzyskanie przy rozkładzie każdego $z$ nich tego samego produktu - hemipirolu. Publikację o wynikach przygotował Nencki razem $z$ Leonem Marchlewskim. Była ona ukończona na niecałe
5 miesięcy przed śmiercia profesora i wysłana do druku w 1901 r., a opublikowana w 1902 r. Podsumowując wyniki tych badań Nencki podkreślał ich zasadnicze znaczenie dla chemii biologicznej, ponieważ wyniki te „rzucaja światło na najodleglejsze momenty w historii rozwoju zorganizowanego świata" i świadczą o „wspólnym pochodzeniu królestwa zwierząt i roślin”. „Teoria Darwina o pochodzeniu gatunków - pisał Nencki opiera się na zmienności form $\mathrm{w}$ zależności od różnych warunków życia w walce o przetrwanie. Różnorodność organizmów wyraża się nie tylko $\mathrm{w}$ formie i budowie narząów, ale także w chemicznym składzie wiązań, $z$ których powstaja żywe komórki. Dlatego dla głębszego zrozumienia historii rozwoju zorganizowanego świata konieczne jest porównywanie nie tylko form, ale także składu chemicznego komórek, a także procesów przemiany materii". Tak więc, Nencki nakreślił rozwój w przyszłości biochemii porównawczej i ewolucyjnej. Ewolucyjne znaczenie biochemicznych badań Nenckiego zostało docenione przez jemu współczesnych na początku $\mathrm{XX}$ wieku.

W marcu 1897 r. w IIEM uroczyście obchodzono 50. rocznice urodzin oraz 25. rocznice działalności naukowej i pedagogicznej Marcelego Nenckiego i $z$ okazji tych jubileuszy zostały opublikowane prace Nenckiego i jego uczniów (Ryc. 4).

W lipcu 1900 r. na Zjeździe Przyrodników i Lekarzy zorganizowanym w Krakowie Nencki wystapił $z$ odczytem pt. "O problemach chemii biologicznej", w którym nakreślił główne kierunki przyszłych prac badawczych. Był on jednym z pierwszych, którzy badali problemy infekcji mieszanych na podstawie ogólnych poglądów o synergizmie i antagonizmie bakterii. Znaczna uwage poświęcali przedstawiciele szkoły Nenckiego badaniu procesów chemicznych przy rozpadzie białka i fermentacji węglowodanów. Teore-

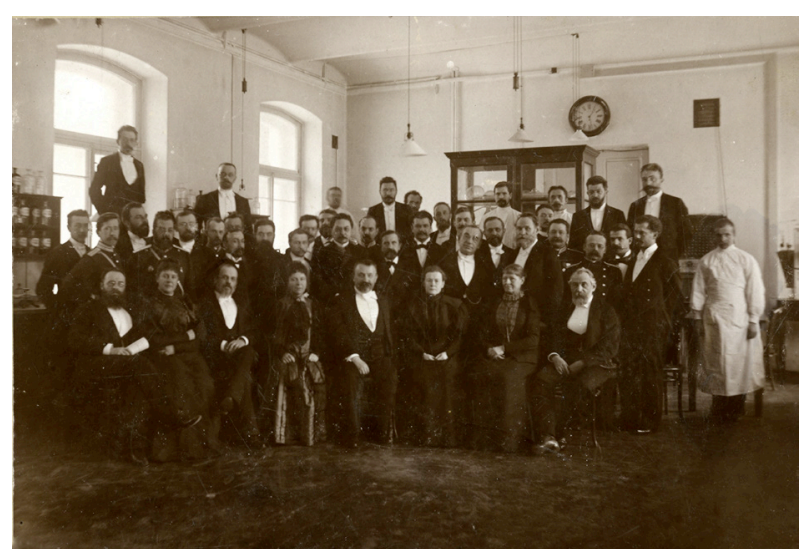

Ryc. 4. Obchody 25-lecia działalności naukowej i pedagogicznej Marcelego Nenckiego 
tyczne i praktyczne znaczenie miały także badania preparatów chemicznych i czynników fizycznych dla dezynfekcji.

Profesor Włodzimierz Engelhardt pisał, że Nencki posiadał fenomenalna pamięć i był wyjątkowo pracowity. Przez 30 lat pracował dzień po dniu w laboratorium od 8.00 do $18.00 \mathrm{z}$ przerwa na obiad. U schyłku życia miał on w pełni prawo być dumnym, że wykonał w swoim życiu dużo ponad 1000 podstawowych analiz organicznych. Swoje dwumiesięczne letnie wakacje spędzał w ukochanym Bernie, gdzie pracowal nad artykułami naukowymi lub urzadzał spacery z przyjaciółmi i uczniami, podczas których prowadzone były ożywione rozmowy na tematy naukowe. Nencki podtrzymywał naukowe kontakty $z$ Iwanem Pawłowem, chemikiem Friedrichem Beilsteinem, pediatra Karolem Rauchfusem. W 1901 r. Nencki zarekomendował profesora Iwana Pawłowa do Nagrody Nobla i w 1904 r. Pawłow został jej laureatem.

Marceli Nencki zmarł 1. (14).10.1901 r. na raka żołądka. Trumnę $z$ jego ciałem Szymon Dzierzgowski przywiózł do Warszawy, gdzie Nencki został pochowany na cmentarzu ewangelicko-reformowanym w Warszawie. W październiku 1901 r. profesor Sergiusz M. Łukjanow, dyrektor IIEM wystapił Z pożegnalnym przemówieniem na pogrzebie Nenckiego, a profesor S. S. Sałazkin, oceniając działalność naukowa zmarłego pisał: „Rzadko praca była przypadkową: większość $z$ nich łączy wspólna myśl i rozwiazaniem jednego lub drugiego problemu coraz bardziej prowadziło Nenckiego do określonego, zamierzonego przez niego celu - do wyjaśnienie przebiegu i charakteru procesów zachodzących w zwierzęcym świecie, aby w ten sposób wyciągnać wnioski o ogólnych biologicznych własnościach".

Jest oczywiste, że Nencki nie mógł nie zauważyć słabości biochemii pod koniec XIX wieku, nieobecności w niej rozwiniętego dynamicznego kierunku. Biorac pod uwage metabolizm u mikroorganizmów, roślin i zwierząt naukowiec mógł sądzić o nim tylko po fragmentarycznych danych. Badacze w tamtych latach byli pionierami biochemii i nieustannie napotykali liczne trudności. Uważano, że biochemia była w tamtych czasach czysta chemia preparatywna, dlatego zadaniem badacza było izolowanie w czystej postaci, najlepiej krystalicznej, chemicznych substancji do badania ich struktury i właściwości. $\mathrm{Na}$ podstawie tego rodzaju badań wyciagano pośrednie wnioski o procesach, w rezultacie których powstała taka lub inna substancja, o jej uczestnictwie w procesach wymiany energii. W całości znaczenie prac Nenckiego i jego uczniów zawiera się w tym, że oni po raz pierwszy zademonstrowali złożoność struktury powstającej nowej dziedziny nauki - biochemii. Uważa się, że był to klasyczny model przejścia od fizjologiczno-chemicznych do prawdziwych badań biochemicznych. Dlatego składajacc hołd zasługom wybitnego naukowca, po jego śmierci koledzy, uczniowie i przedstawiciele polskiej społeczności w Sankt-Petersburgu zorganizowali zbiórkę pieniędzy na fundusz imienia profesora Marcelego Nenckiego w celu wspierania badań biochemicznych. Księżna Eugenia Oldenburgska zwróciła się 5 stycznia 1902 r. ze specjalnym reskryptem do Ministra Spraw Wewnętrznych Dymitra Sipiagina, proszac go o pozwolenie na legalna publiczna zbiórkę. Profesor Sergiusz Łukjanow 29 stycznia 1902 r. na posiedzeniu Rady Naukowej IIEM powiadomił, że na fundusz imienia zmarłego profesora Marcelego Nenckiego wpłynęła darowizna w wysokości 1.000 rubli od księcia Aleksandra Oldenburgskiego i 500 rubli - od księżnej Eugenii Oldenburgskiej.

W 1903 r. w holu gmachu Wydziału Chemii odsłonięto popiersie Marcelego Nenckiego (Ryc. 5) dłuta rzeźbiarza Antoniego Olesińskiego (1857-1904), opłacając jego pracę $z$ zebranych pieniędzy. 22 lutego $1907 \mathrm{r}$. dyrektor IIEM profesor Walery Podwysocki zaproponował w dyskusji na Radzie Naukowej Instytutu tekst „Regulaminu nagrody Nenckiego", opracowany przez niego wspólnie $z$ Nadieżda Ziber-Szumową. Powiedział on również, że majac środki na te cele w wysokości 5.000 rubli można już corocznie wypłacać stażystom odsetki w formie premii. Pierwsza nagroda została przyznana stażyście z Wydziału Chemii A. S. Staniszewskiemu w grudniu 1907 r., a w 1911 r. nagrodę otrzymał Michał W. Czernorucki.

Nadieżda Ziber-Szumowa w artykule o życiu i pracy swojego nauczyciela i mento-

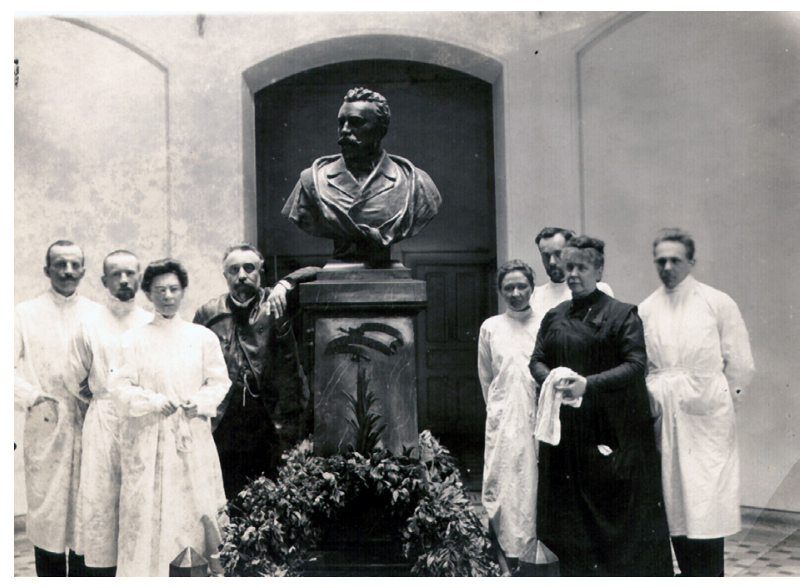

Ryc. 5. Popiersie Marcelego Nenckiego w holu na I piętrze w Laboratorium Chemii (1903 r.) 
MARCELI NENCKI

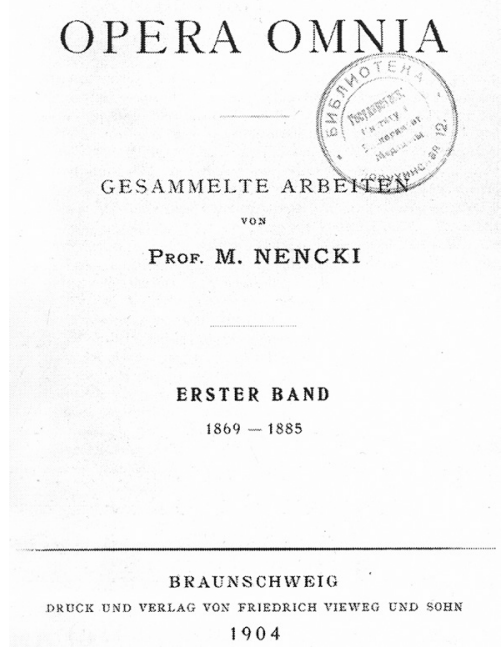

Ryc. 6. Strona tytułowa „Marceli Nencki. Opera Omnia".

ra wyróżniła trzy główne kierunki w szerokim spektrum jego naukowych poszukiwań: chemia organiczna, fizjologia i bakteriologia (ogólna i medyczna). W czasie pracy Nenckiego w Instytucie w jego laboratorium opublikowano w Rosji i za granica 139 artykułów naukowych. Osiagnięcia szkoły naukowej uczonego, wydane w jezyku niemieckim w 2 tomach w 1904 r., zawieraja ponad 150 publikacji samego Nenckiego i ponad 440 prac jego studentów, zajmujac łącznie ponad 1700 stron.

Należy zauważyć, że stałych pracowników naukowych w laboratorium było nie więcej niż 2-3 osoby, ale były „miejsca do pracy”, gdzie za opłata 25 rubli rocznie przyjmowano praktykantów (lub stażystów), którzy chcieli zapoznać się $z$ nowymi metodami badawczymi lub wykonywać część pracy magisterskiej. W laboratorium Nenckiego, a następnie u Ziber-Szumowej pracowali również lekarze weterynarii i farmakolodzy. Każdego roku pracami doświadczalnymi zajmowało się średnio $15-20$ osób. $Z$ reguły przez rok nie była możliwa realizacja całego zakresu badań wymaganych dla rozprawy doktorskiej lub magisterskiej, gdyż praca stażysty trwała zwykle 2 do 3 lat. Całkowita liczba takich praktykantów i stażystów za życia Nenckiego przekroczyła 200 osób, co oznacza, że zaistniała szkoła naukowa profesora Marcelego Nenckiego.

Po odzyskaniu przez Polskę w 1918 r. niepodległości, pozostała część finansowa funduszu im. Marcelego Nenckiego została przekazana do Warszawy przez Szymona Dzierzgowskiego, gdzie została wręczona Towarzystwu Naukowemu Warszawskiemu na organizację Instytutu Biologii Doświadczalnej im. Marcelego Nenckiego ${ }^{2)}$. Temu Instytutowi Nadieżda Ziber-Szumowa też zapisała w spadku część osobistej (obcojęzycznej) biblioteki, jak też prawo na wydawanie dzieł profesora Marcelego Nenckiego.

Tylko 10 lat przypadło pracować Marcelemu Nenckiemu w Rosji, ale jego dokonania $z$ tych lat stanowia najbardziej fascynujacca stronę w biografii naukowej tego wybitnego naukowca: nauczyciela, wiernego syna swojego kraju (Polski), $z$ imieniem którego nierozerwalnie zwiazana jest historia organicznej i fizjologicznej chemii (biochemii), a także rozwój bakteriologii na przełomie XIX i XX wieku. Prawie pełna lista jego licznych prac, w tym we współautorstwie, jest podana w „Marcel Nencki. Opera Omnia. Gesammelte. Arbeiten von prof. M. Nencki“ (Braunschweig, 1904) (Ryc. 6).

\section{MATERIAŁY ŹRÓDEOWE}

Архив Музея истории ИЭМ. Бумаги принца А. П. Омьденбургского.

Архив ФСБ. Справка из архива Управления ФСБ по СПб и Аенинградской области о М. Г. Тартаковском.

Владимиров А. А., 1991. Воспоминания микробиолога. М., 112 с. Временный Устав ИИЭМ. 1891.

Ган М., Массен В. Н,. Неникий М. В., Павлов И. П., 1892. Экковский свищ вен нижней полой и воротной и его последствия дия организма. Архив биол. наук. Т. 1.

Голиков Ю. П., 1999. Эдуард Шперк - первый директор ИИЭМ. Немцы в России: Петербургские немцы. СПб., С. 579-593.

Голиков Ю. П., Денисенко А. Д., Парфенова Н. С., 2011. Биохимия. 12. Т. 77. В. 1.С. 140144.

Голиков Ю. П., Дыбовский А. П., 2012. Маркел Вильгельмович Ненцкий. Природа., № 7 .

Голиков Ю. П., Аанге К. А., 1990. Становмение первого в России исследовательского учреждения в области биологии и медицины. Первый в России исследовательский центр в области биологии и медицины. $\Lambda$., С. 7-43.

Зибер-Шумова Н. О., 1904. Очерк научной деятельности М. В. Ненцкого. Архив биол. Hayk. T. 11. № 3. С. 165-194.

Иванов И. И., 1906. Искусственное оплодотворение у млекопитающих. Архив биол. Наук. Т. 12. В. 4-5, С. 376-509.

Климов А. Н., Голиков Ю. П., Парфенова Н. C., 2011. Маркел Вимьгельмович Ненцкий. Биохимия. № 5 .

Конников А. П., Соловъев А. Т., 1941. Отдем биохимии за 1891-1937 гг. Материалы к истории ВИЭМ. 1890-1932. М., С. 50-62

Аитвинова H. Д., 1959. Роль Института экспериментальной медицины в борьбе с чумой крупного рогатого скота в России. Ежегодник ИЭМ АМН СССР. $\Lambda .$, С. 503505.

Мартинсон Э. Э., 1953. М. В. Ненцкий и его работы по органической химии. МатериаАы по истории отечественной химии. М., С. 105- 117 
Неникий М. В., Мархлевский А. П. Т., 1902. $\mathrm{K}$ вопросу о химическом характере хлорофимла. Получение гемопиррола из фимлоцианина. Архив биол. наук. Т. 9. № 4., C. 387-390.

Неникий М. В., Залесский И. А., 1902. О продуктах восстановцения гемина при действии йодистого водорода и йодистого фосфония. О строении гемина и его производных. Архив биол. наук. Т. 9. № 4. C. 371-386.

Отчет комиссии. Иммунизация животных против чумы рогатого скота и мечение этой болезни. Экспериментальное исследование. АВН. Кн. 1. СПб., 1899. С.: 1-30, 119-159, 191-221. (Тип. МВД, отд. оттиск. 108 с.).

СПБ ГИА. Ф. 2288. ОП. 2. Д. 112. А. 1-3.

СПбИА. Ф. 2282. Оп. 2. Д. 98 (цичное демо М. Ф. Васильева).

Тартаковский $M$. Г., 1895. О восприимчивости верблюдов к чуме рогатого скота. Архив биол. наук. Т. 8. С. 11-356.

Турчинович-Выжникевич В., 1899. современном состоянии предохранительных прививок против чумы рогатого скота. СПб., 192 с.

Файтелъберг-Бланк В. Р., Гуска Н. И., Вериго Б. Ф., 1975. Страницы жизни. Кишинев. $36 \mathrm{c}$.

Шамин А. Н., 1994. История биологической химии. М., 205 с.

Этельгардт В. А., 1951. М. В. Ненцкий (К 50-летию со дня смерти). Биохимия, Т. 16. B. 5. C. $486-494$.

Nencki M., 1904. Opera Omnia. Gesammelte. Arbeiten von prof. M. Nencki. Zweiter band. 1886-1901. Braunschweig, 894 p.

Szwejcerowa Z. A., Groszyńska J. M., 1956. Nencki. Materiały biograficzne i bibliograficzne. Warszawa.

\section{PRZYPISY TEUMACZA}

1) Instytut istnieje nadal pod tym samym adresem i oficjalną nazwą: Федеральное государственное бюджетное научное учреждение „Институт экспериментальной медицины". (Instytucja naukowa Federalnego Budżetu Państwa „Instytut Medycyny Doświadczalnej”).

2) Marzeniem Marcelego Nenckiego było utworzenie w Warszawie placówki naukowej z zakresu nauk biomedycznych. Dlatego też uczniowie i współpracownicy Nenckiego, wkrótce po jego śmierci podjęli starania o utworzenie takiej placówki zwiazanej z jego imieniem, jednakże w zaborze rosyjskim idea ta była niemożliwa do zrealizowania. Udało się ja wcielić w życie dopiero w odrodzonej Rzeczypospolitej, gdy powołano Instytut Biologii Doświadczalnej w Warszawie. Do powstania i rozpoczęcia działalności Instytutu w 1918 r. wydatnie przyczyniło się przekazanie na cele organizacyjne pozostałej części funduszu im. M. Nenckiego, utworzonego po śmierci Nenckiego w Sankt-Petersburgu, a także podarowanie 50.000 rubli w 1909 r. przez Nadieżdę Ziber-Szumowa, asystentkę Nenckiego. 